\title{
Legal Aspects of Medical Records and Data Security for Patients in Hospitals
}

\author{
Deddy Tedjasukmana ${ }^{1}$, Riswadi ${ }^{2}$ \\ Student Program Doctor of Law Borobudur University, Jl. Pemuda, RT.1/RW.3, \\ Rawamangun, Kec. Pulo Gadung, DKI Jakarta 13220, Indonesia ${ }^{1,2}$ \\ \{Deddytedjasukmana60@gmail.com¹,riswadi@borobudur.ac.id²\}
}

\begin{abstract}
This paper aims to analyse the legal aspects of medical records and data security from patients' medical records in the hospital. Medical records have information standards for administrative, legal, financial, research, educational, and documentation aspects. However, to access data from the results of medical records, of course, the hospital must go through the patient's consent as part of the patient's legal protection. Patients have the right not to publish data from the results of their medical records. This paper uses a normative juridical research method by looking at the context of protecting medical record data from patients in the hospital.
\end{abstract}

Keywords: Legal Aspect; Medical Records; Data Security

\section{Introduction}

Times have changed from various aspects. The world of health is not left to keep up with the times. Information technology is becoming the driving force of the change. One of the uses of information technology (IT) in health that is becoming a trend in health services globally is the electronic medical record. In Indonesia, it is known as Electronic Medical Record (RME).

Administratively, electronic medical records are useful as an electronic repository of information about patients' health status and health services throughout their lives. Also, electronic medical records benefit doctors and healthcare workers in accessing patient data, ultimately helping in clinical decision-making. Medical record keeping is mandatory for doctors and dentists who perform medical procedures on patients according to the rules. There is no reason for doctors not to make such medical records. Electronic medical records are a solution for hospitals to overcome various hospitals such as large storage areas, loss of medical records, the expenditure of data needed, and others.

The security of medical record data is reviewed in terms of physical files in the hospital is safe. The ink selected in writing, recording, and printing out on the medical record file is clear, uniform, flat, and easy to read. The paper used by HVS paper with A4 size weighs 70 grams and does not tear easily. According to Huffman, the form used is relatively clean, strong, and has good quality removal and permanence (Huffman et al. 1994). The medical record file map used in hospitals is usually made of cardboard. The material used to make the medical record folder is thick and not easily torn like manila paper or other strong cardboard (WHO 2006). The paper material and medical record file folder in the hospital are strong enough and not 
easily torn. According to Sudra, the medical record map contains at least information about the history of the patient's disease and the history of treatment (Sudra 2013).

A crackdown on cybercrime is due to a lack of system management, a lack of IT employees' TRAINING, and a lack of campaigns about user cybersecurity awareness. The company that provides the solution also ensures the data centre's security, and cloud computing sees three things that can be done to secure medical record data in the hospital. One of them implements firewall solutions and intrusion prevention system at the network gate.

\section{Methods}

This paper uses normative juridical research methods by looking at the context of protecting medical record data from patients in hospitals. Analyse the legal aspects of medical records and data security from patients' medical records in hospitals. Medical records have information standards for administrative, legal, financial, research, educational, and documentation aspects.

\section{Results and Discussion}

\subsection{Legal Protection of Medical Records}

The patient's medical record's legal protection became a hot conversation recently, especially related to the medical history of patients infected with Covid-19 (Prananda 2020). Law No. 36 of 2009 on Health (UUK) was passed on October 13, 2009, and included in the State Gazette of the Republic of Indonesia No. 1441, Supplement to the State Gazette of the Republic of Indonesia No. 5063. This law replaces the old UUK, namely Law no. 23 of 1992 on health. According to Paulinus Soge (2010: 6), one of the reasons for the change is because Law No. 23 of 1992 was made before IcpdKairo 1994, so that there is not much regulation about women's reproductive rights.

In the considered point, a UUK affirmed that health is a human right and one of the elements of welfare that must be realised following the Indonesian nation's ideals referred to in Pancasila and the 1945 Constitution. Even UUK contains a new paradigm that is a healthy paradigm following what was proclaimed by ICPD Cairo in 1994. This is seen in the General Explanation of UKK, which among others, states that "For that, it is time we see the issue of health as a major factor and valuable investment whose implementation is based on a new paradigm commonly known as the healthy paradigm, namely the health paradigm that prioritises promotional and preventive efforts without neglecting curative and rehabilitative efforts" (Retnowati 2013).

With the new paradigm, the government is obliged to realise and improve public health that needs to be supported by patients' legal protection stipulated in Articles 56, 57, and 58 UUK. Article 56 paragraph (1) specifies that everyone has the right to receive or reject some or all of the relief measures given to him after receiving and understanding the information about such actions completely. Paragraph (2) specifies that the right to accept or reject as referred to in paragraph (1) shall not apply to a. people with diseases whose disease can be rapidly transmitted into the wider community; $b$. the state of an unconscious person; or $c-$ severe mental disorders. Paragraph (3) specifies that the provisions on the right to receive or 
reject as referred to in paragraph (1) shall be stipulated following the laws and regulations' requirements.

Article 57 paragraph (1) specifies that everyone is entitled to the secret of his/her personal health condition that has been submitted to the health care provider. Paragraph (2) determines that the provisions on the right to confidential individual health conditions as referred to in paragraph (1) shall not apply in the case of (a) statutory orders; (b) court order; (c) the relevant permit; the interests of the community; or e. the interests of the person.

Pasa 158 ayat (1) determines everyone has the right to claim compensation against a person, health workers, and health operators who cause losses due to errors or omissions in the health services received. Paragraph (2) specifies that the compensation referred to in paragraph (1) does not apply to health workers who perform lifesaving or disability prevention measures in an emergency. Paragraph (3) specifies that the provisions for filing claims as referred to in paragraph (1) shall be regulated according to the laws and regulations.

Medical records are a guide to the maintenance and health services by health workers to patients. Although confidential, but according to the provisions of Article 10 paragraph (1) point b Permenkes No. 269 / MENKES / PER / III / 2008, medical records can be opened to meet the request of law enforcement officials in the framework of law enforcement on court orders. Even in the provisions of Article 13 paragraph (1) point, b Permenkes stated that medical records could be used as evidence in the process of law enforcement, medical discipline and dentistry and the enforcement of dental ethics. Suppose the data in the medical records show negligence or deficiency in care. In that case, this will be evidence of doctors and hospitals' malpractice and become the basis for hospitals and doctors' juridical accountability to patients.

\subsection{Protection of Patient Data}

Patient data protection is quite important, considering that patient data is a private secret maintained by the hospital where the patient receives health care. The safety of medical record files is reviewed from external factors. All components are not safe, namely other unauthorised parties, earthquakes, dust, and other insects and destructive pests.

The common threat posed when irresponsible people hack patient data is that it will be used to harm patients. of course, from the legal side, it can be categorised into criminal or civil problems if it breaks the patient. Then what kind of data protection needs to be applied by hospitals and the government (Supriyanto 2016). So, in this case, the government needs to safeguard data in the form of big data management in medical records and patient data. So that patients will get protection from the technology side as well as the legal side.

Legal protection of medical records contained in Article 29 paragraph (1) point h UURS affirmed that every hospital should conduct medical records. This provision is in sync with Article 7 Permenkes No. 269/MENKES/ PER/III/2008 concerning Medical Records, which states that health care facilities are obliged to provide the necessary facilities to maintain medical records.

Hospitals are health service institutions that provide individual health services in a plenary manner that includes inpatient, outpatient, and emergency services emergency (Article 1, number 1 UURS). Evidence of these types of services can be known from the types of medical records held by the hospital, namely inpatient medical records, outpatient medical records, emergency patient medical records and medical records for patients in disaster circumstances (Article 3 Permenkes No. 269/MENKES/-PER/ III/2008). 
Because the implementation of medical records is one of the hospital's obligations, the quality of this medical record's performance will be an important component for the issuance of operational permits or extension of hospital operating permits. Related to the implementation of medical records in health facilities, Permenkes No. 269/MENKES/PER/III/2008 on Medical Records determines that administrative actions can be in the form of verbal reprimands, written reprimands up to the revocation of permits (Article 17 paragraph $\{2\}$ ). Therefore, implementing a good medical record will facilitate the granting of both operational permits and the extension of hospital operating licenses.

\section{Conclusion}

Based on the analysis, as stated above, it can be concluded that sticking to the general line of wisdom is the basis. At the same time, the purpose of legal politics in Indonesia, as stated in the Preamble to the 1945 Constitution, is to protect all nations and to advance the general welfare based on Pancasila"', which has been aligned with the new paradigm in the handling of health problems that was proclaimed at iced Cairo 1994 and then described in UUPK, UUK, UURS, and Permenkes No. 269/MENKES/ PER/III/2008 on Medical Records, where it appears that medical records can be used as a means of legal protection against hospitals, doctors and patients whenever there is a legal conflict in the maintenance system and health services involving the three parties.

\section{References}

[1] Arydiana, Febrica, and M.Kes dr. Rano Indradi Sudra. 2015. "Tinjauan Karakteristik Pasien Typhoid Fever Di Rsud Kabupaten Karanganyar Tahun 2013.” Jurnal Rekam Medis IX.NO.1(19979-99551): 23-33.

[2] Huffman, John W, Dong Dai, Billy R Martin, and David R Compton. 1994. "Design, Synthesis and Pharmacology of Cannabimimetic Indoles." Bioorganic \& Medicinal Chemistry Letters 4(4): 563-66.

[3] Kurniawati, D., and A S Wariyanti. 2016. "Analisis Kuantitatif Kelengkapan Dokumen Rekam Medis Rawat Inap Pasien Renal Colic." Rekam Medis X (2): 1-12. https://ejurnal.stikesmhk.ac.id/index.php/rm/article/view/624.

[4] Prananda, Rahandy Rizky. 2020. "Batasan Hukum Keterbukaan Data Medis Pasien Pengidap Covid-19: Perlindungan Privasi VS Transparansi Informasi Publik." Law, Development \& Justice Review 3(1): 142-68.

[5] Retnowati, Anny. 2013. "Politik Hukum Dalam Menata Rekam Medis Sebagai Sarana Perlindungan Hukum Terhadap Rumah Sakit, Dokter, Dan Pasien.” Yustisia 2(2): 14454.

[6] Sari, Emina, and Sri Mulyono. 2016. "Tinjauan Fitur Keamanan Data Pasien Pada Sistem Informasi Manajemen Puskesmas Di Puskesmas Polokarto Kabupaten Sukoharjo." Rekam Medis 10(1): 31-38.

[7] Sudra, Rano Indradi. 2013. "Rekam Medis." Tangerang Selatan: Universitas Terbuka.

[8] Susilowati, Indah, Wisnaningsih Surjoseputro, and Dika Silviawati. 2018. "Perlindungan Hukum Terhadap Hak Privasi Dan Data Medis Pasien Di Rumah Sakit X Surabaya." Jurnal Wiyata Penelitian Sains dan Kesehatan 5(1): 5. http://www.ojs.iik.ac.id/index.php/wiyata/article/view/209. 
[9] Supriyanto, Eko Eddya. 2016. “Kebijakan Inovasi Teknologi Informasi (IT) Melalui Program Elektronik Goverment Dalam Meningkatkan Kualitas Pelayanan Publik Di Indonesia." JIP (Jurnal Ilmu Pemerintahan): Kajian Ilmu Pemerintahan dan Politik Daerah 1(1): 141-61. http://governmentjournal.org/index.php/jip/article/view/27.

[10] Wardani, A F K, and S Sugiarsi. 2016. "Analisis Kuantitatif Dokumen Rekam Medis Pasien Rawat Inap Gejala Hematuria Di RSUD Dr. Moewardi.” Rekam Medis X (2): 111. https://ejurnal.stikesmhk.ac.id/index.php/rm/article/view/623.

[11] Wati, V R, and Harjanti. 2016. "Analisis Kuantitatif Dokumen Rekam Medis Pasien Rawat Inap Diagnosis Hematemesis Melena." Rekam Medis X (2): 1-12. https://www.ejurnal.stikesmhk.ac.id/index.php/rm/article/view/633.

[12] WHO .2006. The World Health Report 2006: Working Together for Health. World Health Organization. 